\title{
A COMPARISON OF IMPLICIT VALUES AND EXPLICIT PRICES OF WATER
}

\section{HENNING BJORNLUND and BRIAN O'CALLAGHAN University of South Australia}

\section{ABSTRACT}

This paper reviews the historic relationship between the explicit market price of water entitlements and the implicit value of water when attached to land. Hedonic functions are applied to 246 farm sales during 2001-02 in the Greater Shepparton, Campaspe and Moira areas of northern Victoria in order to establish the implicit value of water. These implicit values are then compared to explicit prices paid for water entitlements during the same period. A longitudinal analysis of this relationship is then conducted based on a similar analysis from the same region during the 1991-93 and 1994-96 periods.It was found that during the early to mid 1990's, the explicit price of water entitlements lagged implicit values as farmers sold unused water which would not compromise the productive capacity of their farms. In 1997, events occurred to push the explicit price above the implicit value during the 1994-96 period. From mid 2002, following a prolonged and increasingly intense drought, the explicit price of water entitlements significantly exceeded the implicit value of water. This caused an increase in the number of land transactions, with many purchasers subsequently selling the attached water entitlements in order to profit from the emerging price gap.

Keywords: Water values, water prices, water markets

\section{INTRODUCTION}

Trading in water entitlements has emerged in all four eastern states of Australia in response to resource demands, resulting in a more efficient allocation of water resources. The traditional connection between land and water entitlements has essentially disappeared, and valuers responsible for farmland valuation, for the purpose of rating and taxes, are now charged with the responsibility of allocating a part of the previous farmland value to the water entitlement. This is largely un-chartered territory for valuation authorities (Bjornlund and O'Callaghan, 2004).

In order to redistribute these values in an equitable manner, methods of separation or deconstruction of value should be developed and applied. In this way, the real value of water when part of an irrigated property can be assigned to the water component. At the 
same time, the value derived from the fact that the property can be supplied with water for irrigation can be assigned to the land.

This study applies the hedonic pricing approach to data collected from an irrigation area in northern Victoria, Australia to ascertain the implicit value of water and thereby establish a methodology to assist rating and taxing valuers to effect this separation of land and water values. The first part of the paper discusses the literature, the second part briefly describes the data used and its sources, and the third part outlines the model specification. The fourth part briefly discusses the results of the hedonic function, while the fifth part provides a longitudinal analysis of the relationship between the explicit market price of water entitlements and the implicit value of water.

\section{LITERATURE REVIEW}

A major determinant of the productivity of agricultural land is the presence of water. This is especially the case in arid and semi arid regions, where the natural precipitation is inadequate or unreliable. A number of studies have therefore paid specific attention to the influence of irrigation water on farmland values. The immediate logic is evident. Farmers value land according to expected productivity and financial gain. The presence of water will enhance the productivity of the land and also the security of its production.

The expectation that the presence of irrigation water increases land values is also supported by the fact that most irrigation water is made available by large public investments in irrigation infrastructure, and government policy has often been to deliver such water at a nominal cost to the farmer. The difference between the value of the increased production made possible by the irrigation water and the charges paid for the water have therefore been capitalized into the value of the land. It can be argued that other farm inputs, such as the farmers' investments in irrigation systems, drainage, pumps, planting etc., create surpluses which are also reflected in land values. It can therefore be said that assigning all the value increase from irrigation to the water component overestimates the value of water. However, the presence of irrigation water is the essential pre-condition for the increased productivity and therefore all the increase in land value should be assigned to water (Renshaw, 1958; Milliman, 1959). If the water is subsequently sold on the market separately from the land, the investments in other farm improvements made by the farmer will lose its productive value. The price of the water should therefore be composed of two components: the capitalized productive value of water, and the capitalized value of all investments that depend on water for profitability (Summers, 1981).

In a hedonic pricing study designed to estimate the value of irrigation water in a study area in Colorado, Hartmann and Anderson $(1962,1963)$ found that the value of irrigated farmland was dependent on geographic location, soil type and land use. They also found that water attached to larger farms became less valuable in line with the per acre 
allocation, and that the value of irrigated land was higher for farms of fifty acres or less, reflecting a consumptive rather than productive use value. In terms of comparison, water market prices generally were higher than the value of water when sold together with land; they also found that the value difference varied depending on the type of water product. It was argued that the reason for this difference was that part of the value of water when attached to land had been capitalized into other water-dependent farm improvements, and that the value of water, land and improvements therefore could not be easily separated.

Royer (1995) applied a hedonic model to estimate the value of water when attached to irrigated land within a study area of southeastern Alberta. The paper analysed 230 farm sales and data were collected in two stages: firstly in the form of generic data from Land Information Alberta on each sold property, and secondly in the form of property characteristics from county land assessors. From the information provided, 23 variables were specified. However, in the final model, only five of these variables were found to be significant: water, building improvements, farm area, the distance to a 'very large city' and the distance to a 'large city'. The study found that farms which had access to irrigation increased in value by $\$ 190$ per acre, adding approximately $35 \%$ to the value of non-irrigated land.

Crouter $(1985,1987)$ studied the implicit water market and analysed transactions of irrigated farmland in Weld County, Colorado. The hypothesis of the study was that in areas where water entitlements are easily transferred separately from land, the hedonic price function for irrigated farm parcels should be separable in land and water, and linear in water. The empirical model developed in the study did not support this hypothesis. Crouter seems to have overlooked the findings of Hartman and Anderson $(1962,1963)$ where water entitlements were found to be tied to significant capital investments in waterdependent farm improvements. Water and land can therefore not easily be separated in its totality, except in areas where local conditions such as soil degradation make these improvements useless and of no value. 
Bjornlund (2001) applied an hedonic function to data collected from the eastern part of Goulburn-Murray Irrigation District (GMID) in Victoria and the Riverland of South Australia to see whether the value of water when attached to land equated to the explicit price of water. At the time of the study, data from 1992-1994 and 1994-96 were used in two different models. A subsequent paper by Bjornlund and Shanahan (2005) used the 1994-1996 data. In this paper, the hedonic model for the GMID was slightly altered by changing two variables: firstly, the variable representing dry land was eliminated due to a high standard error, and secondly the construction of the variable 'unused water' was changed to reflect water used in excess of allocation, and denoted as 'sales water'.

The adjusted model explained approximately the same variation in land price $\left(\mathrm{R}^{2}=0.85\right)$ as the first model. However, the change made to the variable 'unused water' to 'sales water' provided for a more logical interpretation, as the variable measured the volume of water used in excess of water entitlement. That is, the property had the infrastructure in place to utilize the 'sales water' allocation. This suggested that the estimated value of water when attached to land increased from $\$ 432$ to $\$ 584$ per megalitre if the 'sales water' component was used. During this period, entitlements were selling for between \$200 and $\$ 400$ per ML, which fell in the lower half of the estimated confidence interval estimated by the hedonic function, and below the mean value of $\$ 432$, which did not incorporate the 'sales water' component. Bjornlund and Shanahan therefore concluded that water entitlements, when traded in the water market, were undervalued when compared to water attached to land, and that water market prices therefore had a long way to go before equilibrium was reached as buyers pursued the arbitrage advantage. However, the gap between the two was decreasing.

With regard to the ability to separate the value of water from the value of land and waterdependent infrastructure, the research by Bjornlund (2001) and continued in Bjornlund and Shanahan (2005) partly supports the findings of Milliman, and Hartman and Anderson. However, when comparing the hedonic models for three Australian states with different levels of capital intensive production, it was highlighted that the problems associated with separating the value of water from the value of land and water-dependent farm improvements depended on the nature of the agricultural production in the area under investigation. In areas such as the rice-growing district in the Murray Region of NSW, it is generally possible to separate the value of land and water. This is because the

\footnotetext{
${ }^{1}$ Irrigators within the GMID in Victoria have two different water entitlements: 1) a water entitlement with a high level of security of supply (96 years out of 100), and 2) a 'sales water' entitlement. The size of this entitlement varies from year to year and is dependent on the availability of water in the reservoirs. The high level of certainty of water entitlements is ensured by not announcing any 'sales water' for a given season until the next season's water entitlements are secure in the reservoirs. Sales water is announced as a percentage of water entitlement and the long-term average is expected to be $60 \%$, that is, irrigators can use $160 \%$ of their entitlement in an average year.
} 
production does not involve a lot of water-dependent farm improvements, and the improvements that exist can also be used for dry land production. Further anecdotal evidence in the study area suggests that most rice farms sold during the study period had very inefficient improvements, and the irrigation and drainage infrastructure was totally reworked after purchase. The hedonic model, however, suggested that the value of water was more than twice as high if it was applied to permanent pastures for dairy production. This was because dairy production is associated with a high level of investment in waterdependent farm improvements such as permanent pastures, fencing and watering, milking herd, and milking equipment. The latter finding in NSW was clearly reflected within the dairy producing region of northern Victoria. Here the hedonic function could not be easily separated into land, water and improvements. The most complicated relationship between land, water and improvements was found in South Australia, where almost $100 \%$ of irrigation water is used for horticulture and viticulture and where the level of natural precipitation is very low, which means that the productive capacity of these improvements is zero without the presence of irrigation water. Here it was found that the hedonic function could not be separated into water, land and improvements. The value of water was dependent on whether the water was used for vine grape production, citrus production or other horticultural productions, the quality of the plantings on which the water was used, and the quality of the irrigation system used to apply the water.

\section{DATA, DATA SOURCES AND DATA COLLECTION}

Data for analysis were collected from four sources. The Office of the Valuer General (VG) in Victoria provided data relating to 246 land transfers during the years 2001 and 2002 for the Moira, Campaspe and Greater Shepparton areas (similar to the area used by Bjornlund (2001)). This data included sales price, site value, capital value, transfer and settlement date, purchaser and vendor details, land area, CT reference, and plan reference. Based on the data, it was possible to extract information on farm type, arable land area and quality, crop and pasture type and condition rating and value, fencing type and value, irrigation improvements, residential improvements and their value from the records of the rating and taxing valuer in Shepparton. Based on the VG's data and the records kept by Goulburn-Murray Water in Tatura, Victoria, it was also possible to extract information about water entitlements attached to the properties traded and the actual water use prior to sale. Water market prices of water entitlements traded during the same period were provided by Plan Right, Tatura (the largest water broker in the study region) and from GMW.

\section{METHODOLOGY}

In this study, hedonic functions have been applied to transactions of irrigated farmland, in order to identify the value placed on water when traded with irrigated farmland. In this context water is only one of a number of characteristics making up the bundle of goods purchased as a farm. The hedonic theory sets itself apart from property appraisal, by 
shifting the focus of interest from determining the value of the commodity to determining the partial value of its underlying characteristics. Griliches (1971) did some of the early work on hedonic price functions when analyzing car prices. He did so in order to improve the way price indexes are adjusted to distinguish the proportion of price increases caused by quality changes from those caused by inflationary price increases.

The theoretical framework is developed around the fact that many commodities are heterogeneous goods, consisting of a bundle of characteristics in different quantities. These goods cannot be un-bundled, and the characteristics sold separately; neither can they be re-packaged. Buyers in the market are therefore shopping around, finding the bundle of characteristics which best suits their purposes. If enough of such packages, including different quantities of each characteristic, are sold in the market, a hedonic price function can be identified:

$$
\mathrm{P}(\mathrm{Z})=\mathrm{f}\left(\mathrm{Z}_{1} \ldots \ldots \ldots \ldots \ldots \mathrm{Z}_{\mathrm{n}}\right),
$$

where $\mathrm{P}(\mathrm{Z})$ is observed product prices and $\mathrm{Z}_{1}$ to $\mathrm{Z}_{\mathrm{n}}$ is the bundle of product characteristics. Solving this function for a large number of transactions will establish the value of each of the $\mathrm{Z}$ characteristics.

In the process of building the final model, a number of issues have to be considered. One key assumption is that the independent variables, the $\mathrm{Zs}$, in the equation are truly independent, that is, no multicollinearity exists. This is especially important in a study like this, where the emphasis is on the relative magnitude of the estimated coefficients, rather than the predicted value of the dependent variable. To ensure this, scaled condition indexes, and their associated variance-decomposition proportions, have been used (Belsley, 1991). Belsley suggests that a condition index above 30 shows conclusive presence of multicollinearity, and that variables with a variance-decomposition proportion of more than 0.5 are involved in such multicollinearity. Belsley also suggests that if condition indexes exceed 10, then researchers should consider the potential implications of multicollinearity. Other researchers have used VIF figures; the literature suggests different cut-off points as critical VIF values. A cut-off point of 4 would normally be considered conservative.

\section{MODEL SPECIFICATION}

The selection of variables to be used in the model is guided by two parameters; firstly, existing literature, and secondly, data availability. The literature review identified several variables as significant value determinants in the valuation of irrigated farmland. Hartman and Anderson $(1962,1963)$ reported that location, soil type and farm use were significant variables. Dunford et al. (1985) identified soil quality, arable areas, buildings and other improvements, topography, climate and location (distance to town, road access) and availability of water as important factors. Coelli et al. (1991) suggested that purchasers 
include the value of irrigation improvements when assessing the value of a farm. Royer (1995) found that water entitlements, building improvements, farm area and distance were significant variables in estimating the value of irrigated farmland. Xu et al. (1993) identified permanent improvements, regional characteristics, land size, soil quality and water rate per hectare as significant. King and Sinden (1995) recognized land quality as a significant value determinant. Bjornlund (2001) found that water entitlement, quality of dwelling, location and water used for permanent pastures were significant at the 0.01 level.

Based on the literature and the data available from the sources described above, the following independent variables were employed in the model-building process:

- Total water entitlement measured in mega liters (ML) included in the sales price.

- Water use during 2001/02 (measured in ML).

- Water use during 2002/03 (Measured in ML).

- Entitlement per Irrigated Hectare.

- Farm type: Dummy variables for each of the recorded farm activities - dairy, mixed, livestock/horses, fodder production, beef cattle, orchard, and hobby farm.

- Topography: Dummy variables representing categorical rankings associated with topography.

- Shape: Dummy variables representing categorical rankings associated with shape.

- Pasture: A dummy variable representing pasture condition codes.

- Area Irrigated Land, number of hectares of irrigated farmland.

- Area Dry Arable land, number of hectares suitable for dry land cropping.

- Area Low Value, number of hectares not able to be farmed.

- Arable Area Hectares, number of hectares of cropping and irrigated land.

- Area Permanent Pasture, number of hectares in permanent plantings.

- Fencing Value, the dollar value placed on fencing by the valuer.

- Irrigation Improvements Value: the dollar value placed on irrigation improvements by the valuer.

- Farm Building Improvements Value, the dollar value placed on farm buildings by the valuer.

- House Value, the dollar value placed on residential improvements by the valuer.

- Location dummy variables.

The sales were screened and sales between related parties were removed, as were sales without water entitlement attached. The sales were then analyzed for outliers and as a consequence, some transactions at very low prices were removed.

Initially, the full transaction cost was used as the dependent variable and the house value as an independent variable. However, it was found that the coefficient of 'House Value' was not significantly different from one. The dependent variable was recomputed by deducting the value of the house from the transaction price, and thus the new dependent 
variable reflected the price paid for the agricultural component of the property. This follows the approach taken by Crouter (1987) and Bjornlund (2001).

\section{RESULTS}

Two different and significant models were produced using hedonic functions, which are shown in Table 1 . Only variables significant at the 0.1 level or better are reported. The models were built by introducing the anticipated variable into the models individually to test their significance and test for multicollinearity. Two models were chosen in order to explore the link between water and land and improvement values, since this has been identified as one of the main issues identified in the literature review.

In both models, the condition index, as well as the VIF figures, fall well below the critical values, which indicates that multicollinearity is not a significant problem. Notwithstanding this, the VIF and variance-decomposition proportions of irrigated land and water entitlement in Model 2 indicate that some weak multicollinearity may be present.

Both models explain approximately $75 \%$ of the variation in price. Each model produces strong results, with most variables being significant at the 0.01 level. The $F$ value of Model 1 (47.32) is greater than that of Model 2 (40.98), while Model 2 has a lower sum of errors and a marginally higher $\mathrm{R}^{2}$ Choosing the most appropriate model on the basis of these statistics are therefore difficult. Both models contain the same type of variables:

1) A location variable 'Moira' suggesting that properties in Moira were selling at lower prices than in other parts of the study area;

2) farm building value, suggesting that farm buildings were considerably undervalued by the rating and taxing valuer;

3) the water entitlement included in the transaction; and,

4) land area. Model 1 included the total area of arable land, while Model 2 included two variables for land area: i) irrigated land and ii) dry arable land.

The following discussion will concentrate on variables 3 and 4, as they are the key to this research. 
Table 1: Two models: summary

\begin{tabular}{|c|c|c|c|c|c|c|c|c|}
\hline \multirow[t]{2}{*}{ Variable } & \multicolumn{4}{|c|}{ Model 1} & \multicolumn{4}{|c|}{ Model 2} \\
\hline & $\beta$ & Se $\beta$ & VIF & VDP $^{1}$ & $\beta$ & Se $\beta$ & VIF & $\mathrm{VDP}^{1}$ \\
\hline $\begin{array}{l}\text { Water } \\
\text { entitlement }\end{array}$ & 719.06 & $137.76^{* *}$ & 1.881 & 0.84 & 510.68 & $165.98^{* *}$ & 2.891 & 0.92 \\
\hline Moira Area & -56439.42 & 19177.70* & 1.180 & 0.05 & -46491.49 & $19219.01 *$ & 1.254 & 0.11 \\
\hline $\begin{array}{l}\text { Farm Bldg } \\
\text { Value }\end{array}$ & 1.844 & $0.377^{* *}$ & 1.390 & 0.09 & 1.925 & $0.369^{* *}$ & 1.405 & 0.08 \\
\hline $\begin{array}{l}\text { Arable Area } \\
\text { Hectares }\end{array}$ & 1294.13 & $312.82 * *$ & 1.488 & 0.65 & & & & \\
\hline $\begin{array}{l}\text { Irrigated Area } \\
\text { Hectares }\end{array}$ & & & & & 1882.88 & $411.40^{* *}$ & 2.368 & 0.77 \\
\hline $\begin{array}{l}\text { Dry Arable } \\
\text { Land }\end{array}$ & & & & & 787.61 & $386.39^{*}$ & 1.084 & 0.00 \\
\hline CONSTANT & 64357.77 & $18553.09^{* *}$ & & & 64969.50 & $18034.96^{* *}$ & & \\
\hline SEE & 67360.77 & & & & 65471.39 & & & \\
\hline Adjusted $\mathrm{R}^{2}$ & 0.743 & & & & 0.757 & & & \\
\hline F Value & 47.32 & & & & 40.98 & & & \\
\hline $\begin{array}{l}\text { Condition } \\
\text { Index }\end{array}$ & 6.412 & & & & 8.319 & & & \\
\hline
\end{tabular}

Notes: Significance Levels: $* *=0.01 ; *=0.05$. ${ }^{1}$ Variance-decomposition Proportion

Comparing the coefficients for the land and water variables in the two models reveals important relationships between water and land and water dependent infrastructure, as was also found by Bjornlund (2001) and Bjornlund and Shanahan (2005).

Model 1 suggests that water entitlements have a value of approximately $\$ 720$ per ML (with a $95 \%$ confidence interval of $\$ 445$ to $\$ 995$ ) and a value of arable land of $\$ 1,300$ per hectare. Model 2 suggests that the value of water entitlements is only $\$ 510$ per ML (with a $95 \%$ confidence interval of $\$ 180$ to 845 ), but that it has two land values: dry arable land at $\$ 790$ per hectare and irrigated land at $\$ 1,880$ per hectare. The differences between the two coefficients for water entitlements and the land variables support the presence of multicollinearity alluded to above, and stresses the value-link between water and the land and improvements on which it is used.

It is argued that Model 2 suggests that when dry land and irrigated land are represented separately in the model, the productive value of water dependent infrastructure is capitalized into the value of irrigated farmland. The value ascribed to water therefore reflects the value of unused water, and is effectively the price at which irrigators with unused water should be willing to sell their water in the water market. Conversely, Model 1 suggests that when all the arable land is represented as a single variable, the productive value of water-dependent farm improvements is capitalized into the value of the water. The value ascribed to arable land therefore represents the value of the land being able to be irrigated, as the land has access to water supply infrastructure and therefore can be irrigated. In valuation terms, this represents the value of commandable land (land capable of being supplied with irrigation water). On the other hand, the value of water entitlements in this model represents the price that an irrigator should be willing to sell water for if the water is used to support water-dependent farm improvements. For these reasons and for 
consistency with the models used in Figure 1 for the 1992-94 and 1994-96 periods, Model 1 has been used in Figure 1.

\section{RECENT TRENDS IN THE MARKET PRICE AND IMPLICIT VALUE OF WATER}

In a mature market, it could be expected that the price of water entitlements being traded as a separate commodity in the water entitlement market would reflect the value of water when attached to land. When trading was first introduced, many irrigators had more water than they needed. They originally applied for and got water entitlements, but subsequently did not develop their irrigation to a level where they could utilize all the water, or they never developed their property at all. In early immature markets, it could therefore be expected that such unused water would be sold first. Sellers of such water should be willing to sell at a low price since such sales would not reduce the income producing capacity of the property. As unused water is sold and markets mature, it could be expected that the price of water in the market will increase as irrigators are selling water which is actively used to support water dependent farm improvements, and that such sales therefore would reduce the income producing capacity of the property. In maturing markets, it could be expected that the explicit market price for water entitlements should converge with the implicit value of water when attached to and supporting waterdependent farm improvements such as permanent plantings, irrigation and drainage infrastructure, and milking herds and equipment (Bjornlund and Shanahan, 2005). Immature markets are often characterized by thin trading and therefore a high level of price variability, while as markets mature, prices will become more mature. Figure 1 clearly illustrates this. During 1992-94 (the first two years of water trading), price variability was very high. During 1994-96, while prices remained relatively stable, and the market matured, prices were in a relatively narrower band. During periods with a certain shift in the price levels, it must be expected that price dispersion increases as market participants get aware of the new price level. This is clearly illustrated in Figure 1 during the periods from 1997/98 and after 2001.

From January 1991 to December 1993, and from January 1994 until December 1996, the market price of water lagged behind the implicit value of water (Bjornlund, 2001) (Figure 1). This was possibly due to the fact that sellers of unused water dominated the market during this period. Also, very little trading took place, the market was immature, and several trades occurred well below the mean market price. In fact, the majority of sales occurred below the mean implicit value of $\$ 380$ (Bjornlund, 2001). By June 1994, while the implicit mean value of water had increased to $\$ 410$ (Figure 1), the majority of water transfers in the market still traded in the lower end of the $95 \%$ confidence interval. When the value of sales-water was factored in, the mean implicit value of water was $\$ 584$. The level of dispersion around the mean also increased during this time. 
In December 1994, new trading regulations came into force freeing up trade, both spatially and between different types of water entitlements (Bjornlund, 2002). For example, it was made possible to trade between farmers within the GMID and farmers downstream of Nyah, and also between water right holders and license holders ${ }^{2}$. The lifting of spatial restrictions was expected to cause a significant shift of water from within the GMID and downstream to Sunraysia, as water moved from relatively low value users within the GMID to high value horticulture and viticulture users in Sunraysia. However, the first trade from the GMID to Sunraysia did not take place until 1997, when a boom occurred in the wine grape industry (Bjornlund, 2003a; Bjornlund, 2003b). Figure 1 clearly shows the sharp increase in the market price of water from July 1997, to July 1999. In 1997, the price of water rose above the mean implicit value for the 1994-96 period. In September 1998, the first interstate trade took place. Shortly thereafter, the market price of water declined, caused by major wineries ceasing to issue new wine grape contracts effectively barring irrigators from obtaining finance to buy additional water entitlements to expand wine grape production (Bjornlund, 2003b).

${ }^{2}$ Irrigators within the old government irrigation schemes have water entitlements in the form of water rights while irrigators who pumped their own water directly from the river had their water entitlement in the form of a diversion licence. Prior to 1994, trade between the two could not take place. 
Figure 1: Water Prices and Implicit Water Values - Goulburn Murray Irrigation District, Victoria

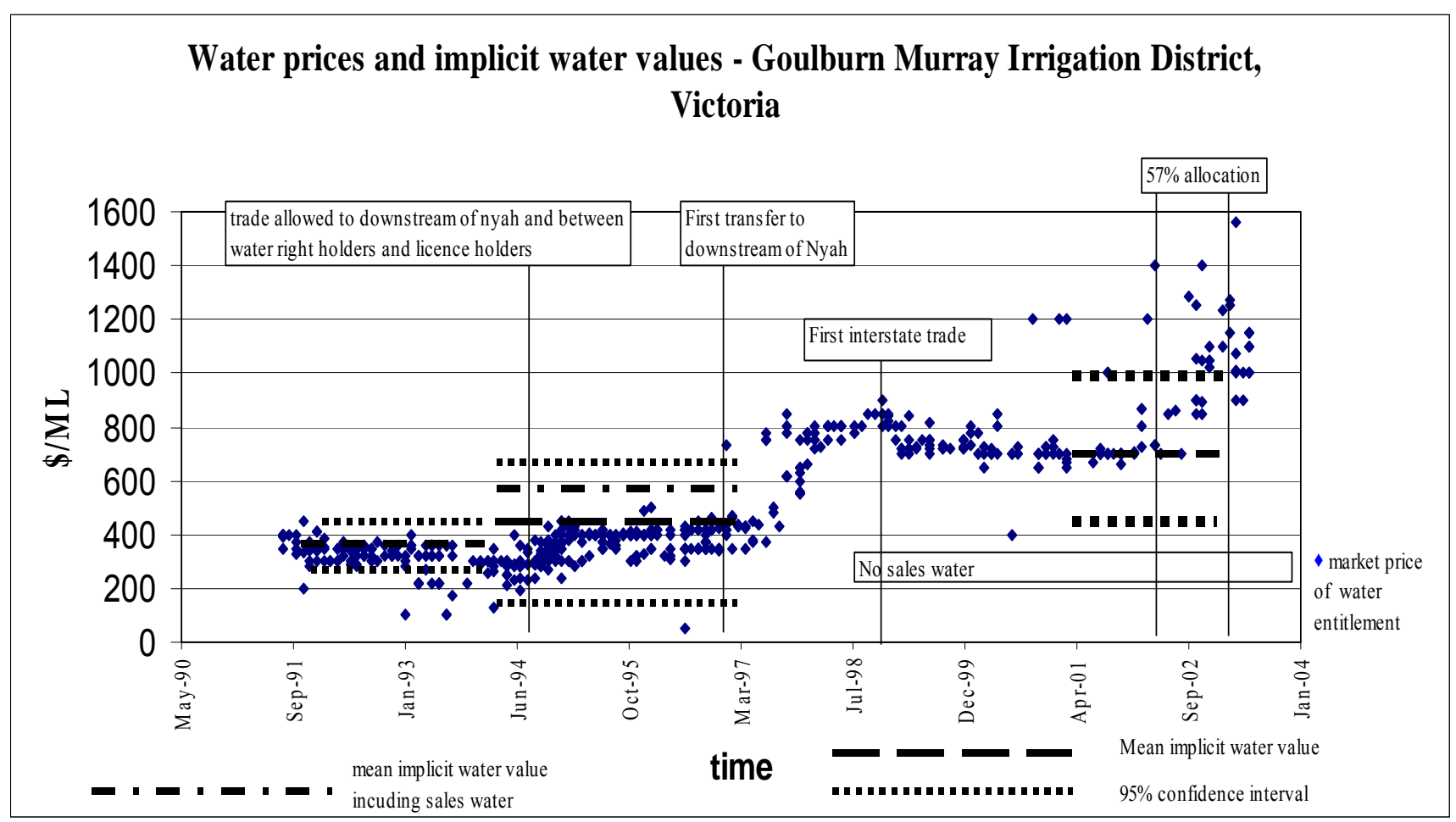


In 2001, the implicit value seems to reflect the explicit price; however the equilibrium was short-lived, as the prolonged drought with no sales-water, which started in July 1998, culminated in 2002/03 (with 56\% allocation) and caused the price of water to increase to well above the mean implicit value, with a large percentage of sales falling beyond the $95 \%$ confidence interval.

The future direction of the market price can take one of two courses: either the market price of water entitlement will fall and come into line with the implicit value of water, or the market price of water entitlements will remain high, and farm prices will be bid up by purchasers taking advantage of the difference between the market price and the implicit value of water entitlements, benefiting from arbitrage. While a difference between value and price remains, it is likely that purchasers will continue to seek to gain some of the difference, and therefore purchase land with attached entitlements, rather than purchase water entitlements in the water market. Focus groups with irrigators in the study region provided anecdotal evidence of an increasing trend that properties were sold with the intend of taking off the water entitlement and sell it in the market or transfer it to the buyer's home farm and leave the purchased property dry (Bjornlund, 2004).

\section{CONCLUSIONS}

This paper has analyzed transactions of irrigated farmland within a study area of northern Victoria to extract the implicit value of water when traded as part of an irrigated farm. This implicit value of water has then been compared with explicit prices paid for water entitlements within the study region during the study period, as well as longitudinally by drawing on past research.

Two different implicit values were identified, depending on how the land area was included in the model. In one model, the land area was included in the form of dry arable land as one variable and irrigated land as another variable. Under this specification, the mean implicit value is estimated at $\$ 510$ per ML, while the value of irrigated land is estimated to be $\$ 1,885$ per hectare, compared to dry arable land with a value of $\$ 790$ per hectare. However, in a second model, all arable land is included as one variable, in which case, the value of water is estimated to be $\$ 720$ per ML, while the value of land is estimated to be $\$ 1295$ per ML. Both models are highly significant and free of multicollinearity using conservative testing limits.

Given these findings, it is argued that: (i) in the first model, the productive value of waterdependent farm improvements is capitalized into the value of irrigated farmland, and the $\$ 510$ per ML therefore represents the price at which irrigators should be willing to sell unused water; and (ii) in the second model, the productive value of water has been capitalized into the value of the water, and the $\$ 720$ per ML therefore represents the price at which irrigators should be willing to sell water actively used to support water- 
dependent improvements. Under the second scenario, it is argued that the ability of the land to be supplied with water is reflected in the predicted land value \$1,295 per hectare.

When separating the value of land and water for the purpose of valuing irrigation farms for rating and taxing purposes, $\$ 720$ per ML should follow the water, while the value of $\$ 1,295$ per hectare should be ascribed to commandable land (land capable of being supplied with irrigation water) as part of the farm value.

During the early years of water trading, the explicit price of water lagged the implicit value of water as irrigators sold unused water not supporting water dependent farm improvements. As unused water was sold, and as competition in the water market was opened up to areas with an expanding viticulture industry, prices increased to match the implicit value of water. As drought conditions intensified, and after four years culminated with allocations of less than water entitlements during 2002/03, the explicit price of water soared and exceeded the implicit value of water. Under this scenario, an increase has been reported in the sale of irrigation farms to benefit from the arbitrage potential generated by this gap. Farms were purchased for the purpose of stripping off the water and selling it separately in the water market or to transferring it to the buyer's home farm.

\section{ACKNOWLEDGEMENTS}

This research is funded by the Australian Research Council and five industry partners: Department of Water Land and Biodiversity Conservation in South Australia, Goulburn-Murray Water and Department of Sustainability and Environment in Victoria, Department of Infrastructure, Planning and Natural Resources in NSW, Murray Darling Basin Commission and UPmarket Software Services. The research could not have been completed without the significant assistance given by the Valuer General in Victoria, Goulburn Murray Water and Plan Right in Tatura, Victoria and the valuer in Shepparton, Victoria.

\section{REFERENCES}

Belsley, D.A. (1991): Condition Diagnostics. Colinearity and Weak Data in Regression. Wiley-Interscience Publication.

Bjornlund, H. (2004): Water markets, Water rights and the Environment - What the Irrigation Community Tells Us, Victoria, New South Wales and South Australia. Industry Partner Report written as part of the ARC SPIRT project Draft Final Report Section 3. For a copy contact the author at henning.bjornlund@unisa.edu.au.

Bjornlund, H. (2003a): Farmer Participation in Markets for Temporary and Permanent Water in Southeastern Australia. Agricultural Water Management 63, 57-76. 
Bjornlund, H. (2003b): Empirical evidence of factors driving prices paid, volumes traded and number of transfers in permanent and temporary markets. Industry Partner Report written as part of the ARC SPIRT project Draft Final Report Section 2. For a copy contact the author at henning.bjornlund@unisa.edu.au.

Bjornlund, H. (2002): Signs of Maturity in Australian Water Markets. New Zealand Property Journal July, 31-46.

Bjornlund, H. (2001): Water Policies and Rural Land Values. Paper presented at the $7^{\text {th }}$ Pacific Rim Real Estate Society Conference, Adelaide January 21-24, www.business.unisa.edu.au/prres.

Bjornlund, H. and O'Callaghan, B. (2004): Property Implications of the Separation of Land and Water Rights. Pacific Rim Property Research Journal 10(1), 54-78.

Bjornlund, H. and Shananhan, M. (2005): Tracing the emergence of water markets along the River Murray in Australia. Submitted for publication in the Journal of Law and Economics. For a copy, contact the authors at henning.Bjornlund@unisa.edu.au.

Griliches, Z. (1971): Hedonic Price Indexes for Automobiles: An Econometric Analysis of Quality Change. In Griliches, Z. (Ed.) Price Indexes and Quality Change. Studies in New Methods of Measurement. Harvard University Press, Cambridge, Massachusetts.

Crouter, J.P. (1985): An Examination of an Implicit Water Rights Market Using Hedonic Estimation. PhD Economics Thesis, University of Illinois at Urbana-Champaign, Urbana, Illinois.

Crouter, J. P. (1987): Hedonic Estimation Applied to a Water Rights Market. Land Economics 63(3), 260-271.

Dunford, R. W., Marti, C.E., Mittlehammer, R. C. (1985): A Case Study of Rural Land Prices at the Urban Fringe Including Subjective Buyer Expectations. Land Economics 61(1), 10-16.

Hartmann, L. M. and Anderson, R. L. (1963): Estimating irrigation water values: A regression analysis of farm sales data from Northeastern Colorado. Agricultural Experiment Station, Colorado State University. Fort Collins, Colorado.

Hartman, L.M. and Anderson, R.L. (1962): Estimating the Value of Irrigation Water From Farm Sales Data in Northeastern Colorado. Journal of Farm Economics 44, 207-213.

King, D. A. and Sinden, J. A. (1995): Influences of Soil Conservation on Farm Land Values. Land Economics 64 (3), 242-255. 
Milliman, J. W. (1959): Land Values as Measures of Primary Irrigation Benefits, Journal of Farm Economics 41, 234-43.

Renshaw, E. F. (1958): Cross-sectional Pricing in the Market for Irrigated Land. Agricultural Economic Research, January, 17-19.

Royer, S.A. (1995): The value of water rights in Southern Alberta: A hedonic price model approach. Unpublished masters thesis, University of Alberta (1995).

Summers, L.C. (1981): An Economic Framework for Valuing Trancient Water Rights in the Arid West. The Appraisal Journal, January, 9-14.

Xu, F., Mittlehammer, R. and Barkley, P. W. (1993): Measuring the contribution of site characteristics to the value of agricultural land. Land Economics 69(4), 356-69. 